\title{
Heat Transfer Characteristics of Bulkhead Penetration Piece for A60 Class Compartment II: Fire Resistance Test for Piece Material and Insulation Types
}

\author{
Woo-Chang Park ${ }^{*}$ and Chang Yong Song $\circledast^{*}$ \\ "Dept. of Naval Architecture and Ocean Engineering, Mokpo National University, Jeonnam, Korea \\ $\mathrm{A} 60$ 급 구획 적용 격벽 관통용 관의 열전달 특성 II: \\ 관 재질 및 단열재 종류에 따른 방화시험 \\ 박우창무 - 송창용(10* \\ *목포대학교 조선해양공학과
}

KEY WORDS: Ship and offshore plant fire accident 선박 및 해양플랜트 화재 사고, A60 class compartment A60급 구획, Bulkhead penetration piece 격벽 관통 관, Fire resistance test 방화 시험, Piece and insulation materials 관 및 단열재 재질

\begin{abstract}
In the case of a fire accident on a ship or an offshore plant, the design of the bulkhead penetration piece must be verified via a fire test procedure (FTP), as specified by the Maritime Safety Committee (MSC). The purpose of this study is to verify both the numerical analysis results and the design specifications for penetration pieces that could be applied to the A60 class bulkhead division. In this study, the FTP was carried out in accordance with the test procedure prescribed in the MSC regulation. In order to review the fire resistance performance according to the material type, bulkhead penetration pieces for the FTP were made from brass, carbon steel for machine structures (S45C), and austenite stainless steel (SUS316). In addition, spray-type insulation and mechanical fastener-type insulation were applied to investigate the fire resistance performance according to the type of insulation. To verify the heat transfer numerical analysis results for the A60 class bulkhead penetrating piece from this test study, the design specifications of the penetrating piece material and the insulation type applicable to a ship and an offshore plant were identified.
\end{abstract}

\section{1. 서 론}

선박 및 해양플랜트 운용 시에 다양한 형태의 제어, 모니터링 및 통신용 케이블 등이 필요하게 되며, 이러한 케이블은 선내 외에 걸쳐 전 영역에 포설된다. 선박 및 해양플랜트 구조 특성 상 여러 격벽(Bulkhead)이 배치되게 되는데, 이러한 케이블이 안 전하게 설치 및 유지보수 되기 위해서 격벽 관통 관(Bulkhead penetration piece, BPP)의 설치가 요구된다. 특히 선박 및 해양플 랜트에 화재가 발생하는 경우에 대비하여 해사안전위원회 (Maritime Safety Committee, MSC)에서 규정한 화재시험절차 (Fire test procedure, FTP)에 따라 적합한 $\mathrm{BPP}$ 설계의 방화성능 을 실증해야 한다(MSC, 2010). $\mathrm{BPP}$ 의 방화시험에서 $\mathrm{MSC}$ 에 규 정된 전용 시편(Structure steel core, $\mathrm{SSC}$ )의 설계 및 제작, 시험 대상 $\mathrm{BPP}$ 과 $\mathrm{SSC}$ 와의 조립, 단열재(Insulation)의 선정, $\mathrm{SSC}$ 의 화
염로(Furnace) 장착, 화염시험 및 분석 등의 일련의 과정들이 수 행되며 높은 수준의 시험 노하우(Know-how)와 많은 시간과 비 용 등이 요구된다.

선박 및 해양플랜트 분야에서 방화시험과 관련된 연구들이 수행되어 오고 있다. Yu et al.(2000)은 내화용 오일붐의 재질 자 체에 대한 내화성을 평가하기 위한 전기로 시험과 실제 유층이 점화된 상황을 모사하는 수조시험 방법을 제시하였다. Grigonis et al.(2011)은 팽창성 화재 방지 코팅의 두께와 열에 노출된 시 간 사이의 관계를 조사하기 위해 14 가지 이상의 상이한 화재 방지 코팅 샘플에 대한 방화시험을 수행하였다. Choi et al. (2013)은 방화 댐퍼의 H-120급 방열성능 확보를 위하여 방화 댐 퍼 블레이드의 방열 유무와 코밍 부위에 적용된 방열재의 두께 를 변화시켜 120 분 탄화수소 화재 조건의 내화 실험을 실시하 였다. Choi et al.(2014)은 FRP 선박을 건조하는 19곳의 조선소를

Received 12 March 2019, revised 4 August 2019, accepted 12 August 2019

Corresponding author Chang Yong Song: +82-61-450-2732, cysong@mokpo.ac.kr, ORCID: http://orcid.org/0000-0002-1098-4205

(c) 2019, The Korean Society of Ocean Engineers

This is an open access article distributed under the terms of the creative commons attribution non-commercial license (http://creativecommons.org/licenses/by-nc/3.0) which permits unrestricted non-commercial use, distribution, and reproduction in any medium, provided the original work is properly cited. 
대상으로 선박 기관실의 난연성 향상을 위해 적용되는 재료의 종류를 조사하였고, 이들 재료를 이용하여 적층 또는 도포 형태 의 14 종의 시험체를 제작하여 국제해사기구에서 규정한 화염전 파성시험 및 소방방재청에서 고시한 방염성능시험을 실시하고 그 결과를 비교하였다. Jang et al.(2014)은 해양플랜트용 H-120 급 방화댐퍼의 열응력해석을 수행한 후 댐퍼 블레이드 및 코밍 방열에 대한 최적 조건을 도출하기 위해 코밍 노출면 방열 두 께와 비노출면 방열 길이를 변수로 하여 내화실험을 통한 비노 출면 방열재와 코밍 표면 온도를 측정하였다.

본 논문은 저자들이 수행한 기존 연구논문(Park et al., 2018) 의 후속 연구로서 앞서 저자들이 수행하였던 $\mathrm{A} 60$ 급 구획에 적 용될 수 있는 $\mathrm{BPP}$ 의 설계와 과도 열전달 수치해석의 결과를 검 증하기 위해 $\mathrm{MSC}$ 에서 규정하고 있는 $\mathrm{A} 60$ 급 방화성능 검증에 대한 화재시험절차와 동일하게 시편의 제작, 온도조건 및 가열 시간 설정, 온도측정 및 분석방법을 준수하여 방화시험 연구를 수행하였다. 방화시험에 적용된 BPP는 앞서 저자들의 수치해석 연구에서 가장 경제성이 우수한 것으로 검토된 $200 \mathrm{~mm}$ 길이의 $\mathrm{BPP}$ 를 대상으로 하였다. 수치해석 결과의 타당성을 검증하기 위해 $\mathrm{BPP}$ 는 수치해석 연구와 동일하게 황동(Brass), 기계구조용 탄소강(S45C), 오스테나이트계 스테인레스 강(SUS316)의 재질 로 각각 제작하여 방화시험을 수행하였다. 또한 단열재의 종류
에 따른 방화성능을 검토하기 위해 분무식 단열재(Spray type insulation)와 부착식 단열재(Mechanical fastener type insulation)를 각각 적용하여 방화시험을 수행하였다. 본 시험연구를 통해 $\mathrm{A} 60$ 급 $\mathrm{BPP}$ 의 열전달 수치해석의 검증과 더불어 실질적으로 선 박 및 해양플랜트에 적용 가능한 $\mathrm{BPP}$ 와 단열재의 설계 사양을 검토하였다.

\section{2. $\mathrm{A} 60$ 급 구역의 화재시험절차(FTP) 규정 (MSC, 2010)}

$\mathrm{MSC}$ 에서는 선박 및 해양플랜트 기자재의 방화성능을 일정한 규정에 따라 검증될 수 있도록 Resolution MSC.307(88) 상에 시 편제작부터 시험방법에 이르기까지 상세한 내용을 명문화하고 있다. 선박 및 해양플랜트에 설치되는 구조나 의장품이 A60급 구역에 대한 방화성능을 만족하기 위해서는 60 분 동안 규정된 화염온도 가열 상태에서 화염이 가해지는 면의 반대쪽에서 측 정된 온도가 $180^{\circ} \mathrm{C}$ 이하가 되어야 한다. 또한 시험과정 동안 화 염이 가해지는 면의 반대쪽 시편과 단열재에서 발화가 발생하 지 않아야 하고, 시편의 과도한 구조적 손상이 발생되지 않아야 한다. 격벽을 관통하는 관의 방화성능 검증시험용 시편은 실제 선박 및 해양플랜트의 설치 조건과 동일하게 평가될 수 있도록

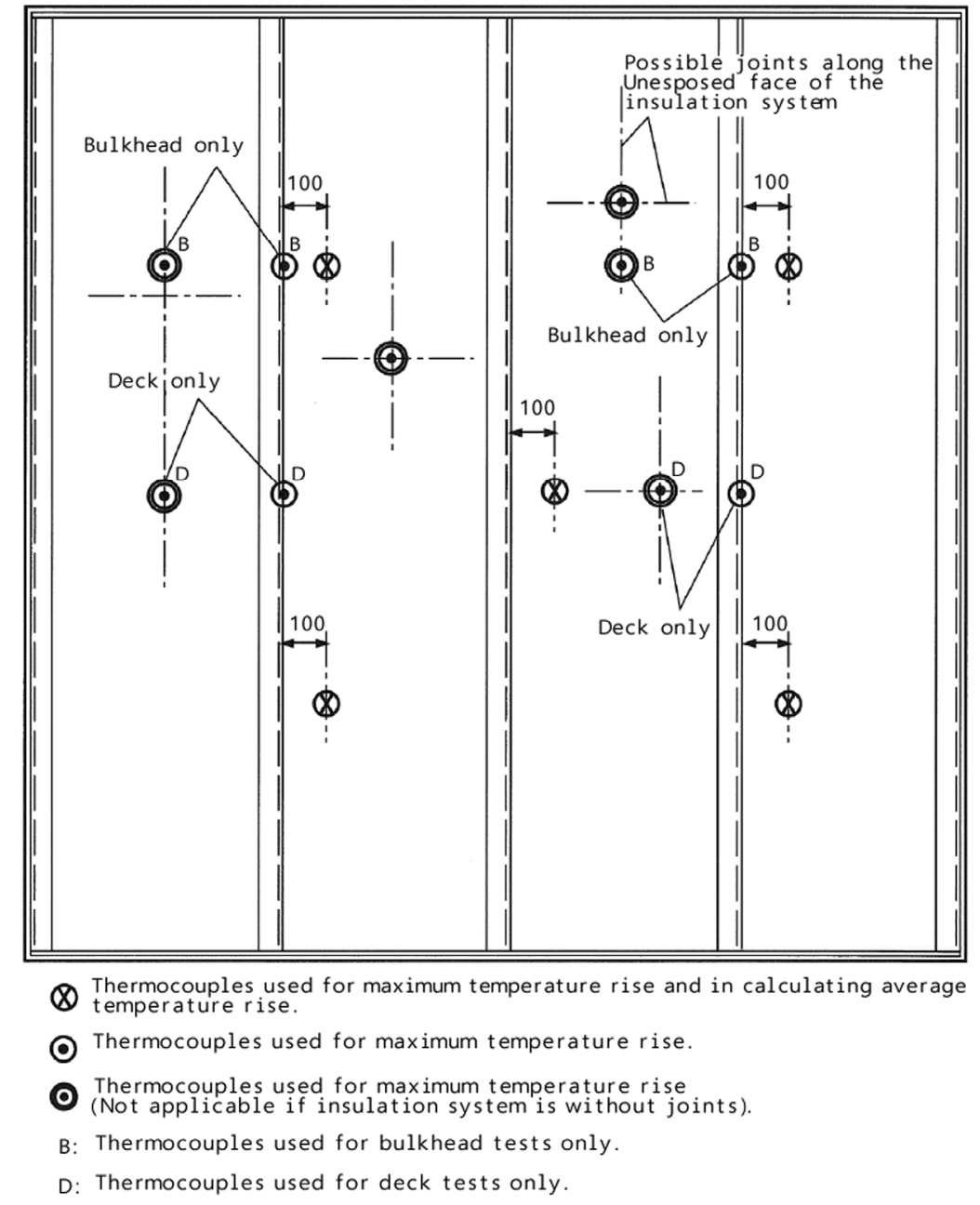

Fig. 1 Position of unexposed-face thermocouples for "A" class division (MSC, 2010) 
단열재는 화염이 가해지는 면의 반대쪽 면에 도포되고 화염로 에 수직으로 장착되어야 한다. $\mathrm{A} 60$ 급 격벽 구역에 대한 화재시 험용 시편인 $\mathrm{SSC}$ 는 강재로 된 용접 구조물로 제작되어야 하며 가로 $2,440 \mathrm{~mm}$, 세로 $2,500 \mathrm{~mm}$, 두께 $4.5 \pm 0.5 \mathrm{~mm}$ 의 평판에 $600 \mathrm{~mm}$ 간격으로 $(65 \pm 5) \times(65 \pm 5) \times(6 \pm 1) \mathrm{mm}$ 의 보강재가 배치되도록 설계되어야 한다. $\mathrm{SSC}$ 는 열팽창에 대한 저항성이 보장될 수 있 도록 $1,600 \sim 2,400 \mathrm{~kg} / \mathrm{mm}^{3}$ 의 밀도를 갖는 두께 $50 \mathrm{~mm}$ 이상의 콘크 리트 혹은 석조(Masonry) 형태의 화염로에 볼트로 체결되어야 한다. 온도측정센서(Thermocouple)는 Fig. 1에 나타낸 바와 같이 단열재가 화염이 가해지는 면의 반대쪽 면에 도포되는 격벽용 $\mathrm{SSC}$ 의(B 측정위치) 경우 평균 및 최고 온도의 측정 목적과 단 열재의 도포 방법에 따라 규정대로 부착되어야 하며, 시험시간 동안 1 분 간격으로 온도가 측정되어야 한다. 본 연구에서는 동 일한 사양의 온도측정센서를 MSC FTP code에서 규정하는 온도 측정 위치에 부착하여 $\mathrm{SSC}$ 의 방화시험 조건을 구성하였다.

시험을 위한 대기온도는 $10 \sim 35^{\circ} \mathrm{C}$ 이며 화염로의 내부 평균 온 도 $(T)$ 는 다음의 조건식에 따라 제어되어야 한다.

$$
T=345 \log _{10}(8 t+1)+20
$$

여기서 $t$ 는 분 단위의 시험 시간을 나타낸다. 식 (1)을 이용하여 화염 시간에 대한 온도 곡선을 도출할 수 있다. 또한 안정적인 화염온도 조건을 유지하기 위해 격벽 $\mathrm{SSC}$ 의 경우, 바닥 높이보
다 $500 \mathrm{~mm}$ 높은 곳에서 압력 값이 0 이 되도록 화염로를 제어해 야 한다.

\section{3. $\mathrm{A} 60$ 급 $\mathrm{BPP}$ 의 방화시험}

\section{1 방화시험 방법}

본 연구에서는 수치해석 연구와 동일하게 $\mathrm{A} 60$ 급 $\mathrm{BPP}$ 의 재질 을 Brass, S45C, SUS316로 각각 적용하고, 단열재의 종류에 따 른 방화성능을 검토하기 위해 분무식 및 부착식 단열재로 각각 적용한 $\mathrm{SSC}$ 를 설계 및 제작하였다. 제작이 완료된 $\mathrm{SSC}$ 를 $\mathrm{KOLAS}$ 공인시험기관에서 화염로에 수직으로 설치 및 $\mathrm{A} 60$ 급 $\mathrm{BPP}$ 의 방화성능 시험을 수행하고 MSC FTP code의 온도 규정 만족여부를 검토하였으며, 기존 저자들이 수행한 연구논문(Park et al., 2018)의 과도열전달수치해석 온도분포 결과와 비교 검토 하였다. 본 논문에서 수행된 일련의 $\mathrm{A} 60$ 급 $\mathrm{BPP}$ 의 방화성능 시 험 과정은 Fig. 2에 정리하여 도시하였다.

$\mathrm{A} 60$ 급 BPP의 방화성능 평가용 설비인 수직화염로는 Fig. 3에 도시한 바와 같이 선박 및 해양플랜트용 $\mathrm{A}$ 급 수직 방화 구획 구성재 등을 시험하는 장비로써 $3,000 \mathrm{~mm} \times 3,000 \mathrm{~mm}$ 이상의 유 효 가열면적이 적용되며, 측면에 배치된 버너를 통해 식 (1)의 시험 온도 곡선으로 화염로 내부 온도를 제어하여 방화 성능을 시험하게 된다(ISO, 1999).

본 연구에서 수행한 $\mathrm{A} 60 \mathrm{BPP}$ 의 방화성능시험 시 수직화염로

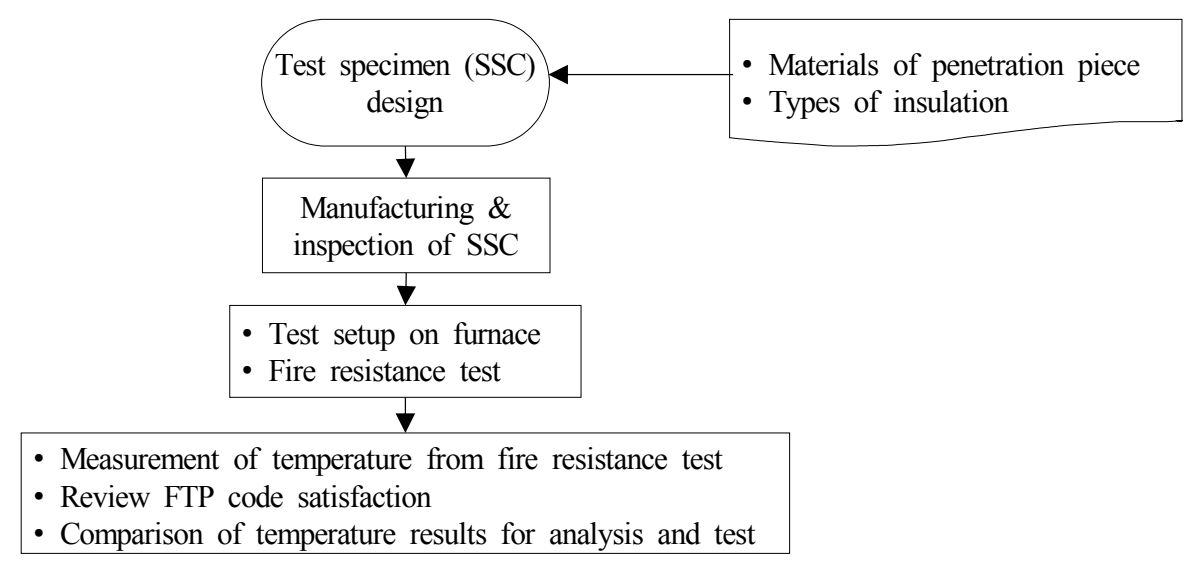

Fig. 2 Fire test flow of bulkhead penetration piece for A60 class compartment
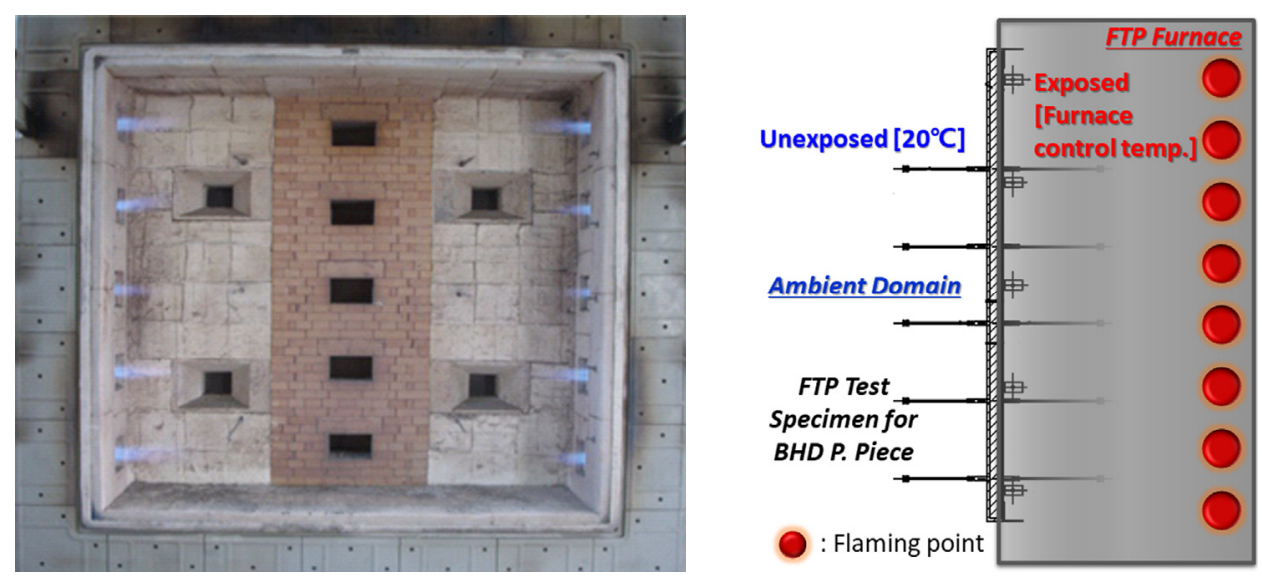

Fig. 3 Vertical furnace(left) and fire test condition(right) (Park et al., 2018) 


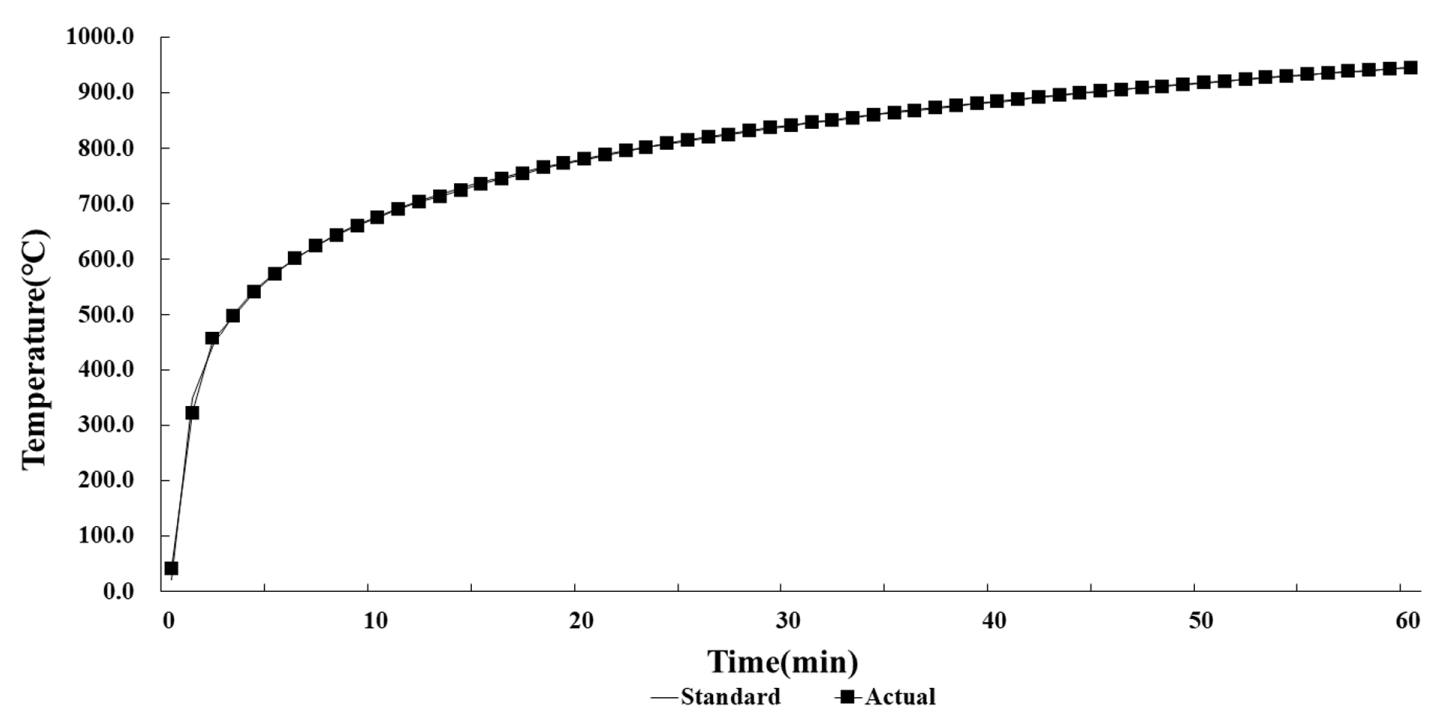

Fig. 4 Verification of time-temperature curve for furnace

내부의 실제 온도 측정결과(actual)와 ISO에서 규정하는 식 (1)의 시험 온도 곡선(standard)과의 비교 결과는 Fig. 4에 나타내었다.

Fig. 4에 나타난 바와 같이 수직화염로 내부의 실제 온도와 ISO 규정 시험 온도 곡선 간의 차이는 거의 발생하지 않았으며, 방화시험 시 MSC. 307(88)에서 규정하는 화염로 내부 시험 온 도 규정을 만족하였음을 확인 할 수 있다.

\section{$3.2 \mathrm{BPP}$ 의 재질에 대한 방화시험 결과}

$\mathrm{BPP}$ 의 재질별 시편은 과도 열전달 수치해석의 결과(Park et al., 2018)를 방화시험을 통해 검증하기 위해 동일한 설계사양으 로 제작 하였다. 열전달 수치해석 연구와 동일하게 가장 경제성 이 우수한 것으로 검토된 길이 $200 \mathrm{~mm}$ 의 $\mathrm{BPP}$ 를 대상으로 하여 직경 $\phi 8$ 의 튜브 및 직경 $\phi 18$ 의 소켓, 직경 $\phi 12$ 튜브 및 직경 $\phi 25$ 의 소켓의 조립체로 구성된 $\mathrm{BPP}$ 를 사용 용도에 따라 튜브가 소켓 내부에서 단절된 절단형(Cutting type)과 튜브가 소켓 내부 를 연속적으로 통과하는 관통형(Passing type)의 설계사양을 고
려하고, Brass, S45C, SUS316의 3가지 재질을 반영하여 총 10 개 의 $\mathrm{BPP}$ 를 제작하였다. 강재로 구성된 $\mathrm{SSC}$ 에 제작된 $\mathrm{BPP}$ 를 조 립한 후 분무식 단열재를 적용하여 방화시험용 $\mathrm{SCC}$ 조립체를 제작하였다. 분무식 단열재로 구성된 방화시험용 $\mathrm{SCC}$ 조립체와 $\mathrm{BPP}$ 의 설계사양 조합은 Fig. 5와 Table 1에 나타내었다. Table 1 에 나타나 있는 $\mathrm{BPP}$ 의 직경 및 재질에 대한 사양 조합은 실제 조선소에서 적용 가능한 설계 사양의 조사를 통해 고려되었다. $1 \sim 5$ 번의 $\mathrm{BPP}$ 는 $\phi 8$ 튜브와 $\phi 18$ 소켓의 조립체로 구성하였고, 6 10번의 BPP는 $\phi 12$ 튜브와 $\phi 25$ 소켓의 조립체로 구성하였다.

튜브 재질이 황동인 경우 용접성 등의 이유로 소켓 재질을 $\mathrm{S} 45 \mathrm{C}$ 로 설정하였으며, 이외의 $\mathrm{BPP}$ 는 튜브와 소켓의 재질을 동 일하게 설정하였다. 또한 1 3번, 6 8번 BPP는 절단형으로 고려 하였으며 4 5번 및 9 10번 BPP는 관통형으로 고려하였다.

Fig. 5와 Table 1에 나타나 있는 사양으로 실제 제작된 분무식 단열재 적용 방화시험용 $\mathrm{SCC}$ 조립체의 형상과 $\mathrm{A} 60$ 방화시험 수행을 위해 수직화염로에 장착된 상태는 Fig. 6에 도시하였다.
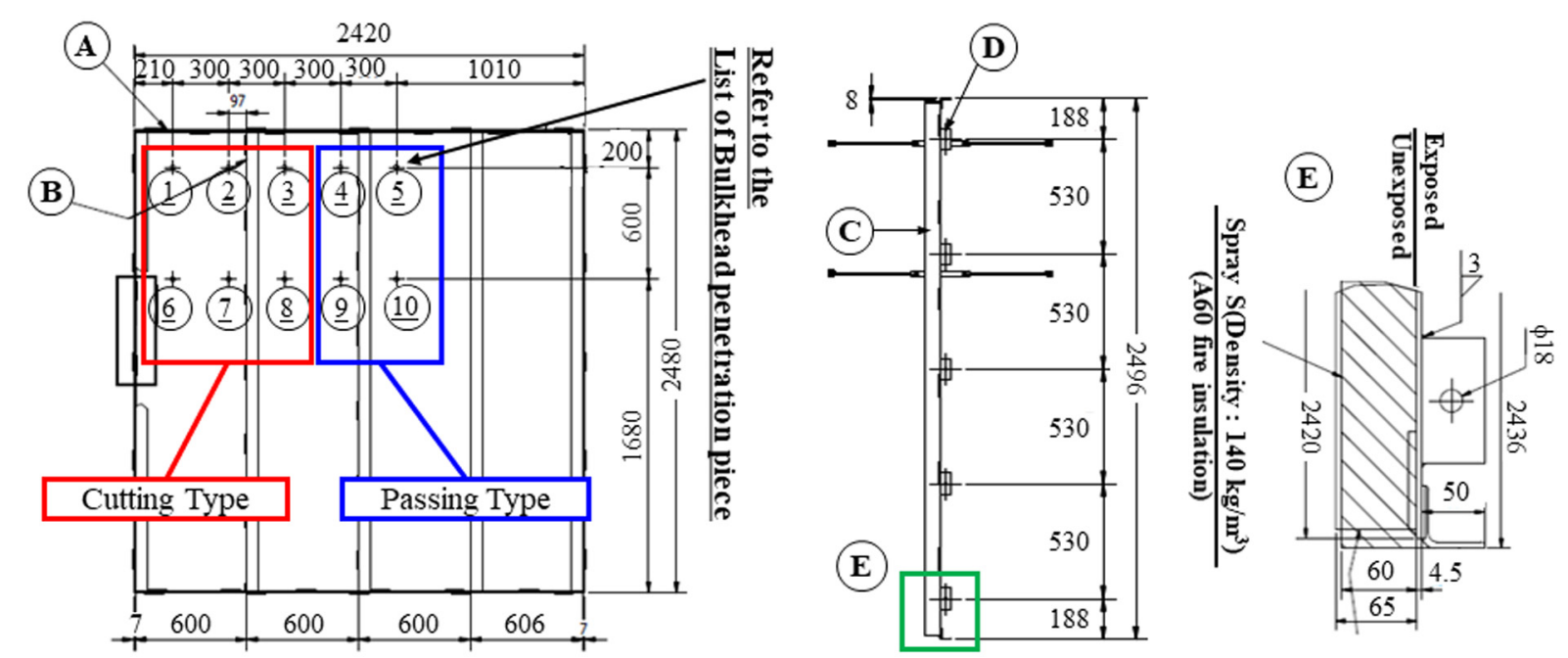

Fig. 5 Fire test specimen design for A60 class bulkhead penetration piece with spray type insulation (Park et al., 2018) 
Table 1 Material type and main dimension of fire test specimen with spray type insulation

\begin{tabular}{ccccc}
\hline \hline No. & Part Name & Main Dimension & Material Type & Piece type \\
\hline 1 & Bulkhead penetration piece & $\phi 18$ Socket $/(\phi 8$ Tube $)$ & SUS316L / SUS316L & Cutting type \\
2 & Bulkhead penetration piece & $\phi 18$ Socket $/(\phi 8$ Tube $)$ & S45C / Brass & Cutting type \\
3 & Bulkhead penetration piece & $\phi 18$ Socket $/(\phi 8$ Tube $)$ & S45C / S45C & Cutting type \\
4 & Bulkhead penetration piece & $\phi 18$ Socket / $(\phi 8$ Tube $)$ & SUS316L / SUS316L & Passing type \\
5 & Bulkhead penetration piece & $\phi 18$ Socket / $(\phi 8$ Tube $)$ & S45C / S45C & Passing type \\
6 & Bulkhead penetration piece & $\phi 25$ Socket / $(\phi 12$ Tube $)$ & SUS316L / SUS316L & Cutting type \\
7 & Bulkhead penetration piece & $\phi 25$ Socket $/(\phi 12$ Tube $)$ & S45C / Brass & Cutting type \\
8 & Bulkhead penetration piece & $\phi 25$ Socket $/(\phi 12$ Tube $)$ & S45C / S45C & Cutting type \\
9 & Bulkhead penetration piece & $\phi 25$ Socket $/(\phi 12$ Tube $)$ & SUS316L / SUS316L & Passing type \\
10 & Bulkhead penetration piece & $\phi 25$ Socket $/(\phi 12$ Tube $)$ & S45C / S45C & Passing type \\
A & Bulkhead plate & $2420 \times 2480 \times 4.5 \mathrm{t}$ & Mild Steel & - \\
B & Bulkhead stiffener & $65 \times 65 \times 6 \mathrm{t}$ & Mild Steel & - \\
C & Sealing & $100 \times 4.5 \times 2420 \mathrm{~L}$ & Mild Steel & - \\
D & Mounting plate & $80 \times 80 \times 4.5 \mathrm{t}$ & Mild Steel & - \\
E & A60 fire insulation & $60 \mathrm{t}$ & Spray S & - \\
\hline
\end{tabular}
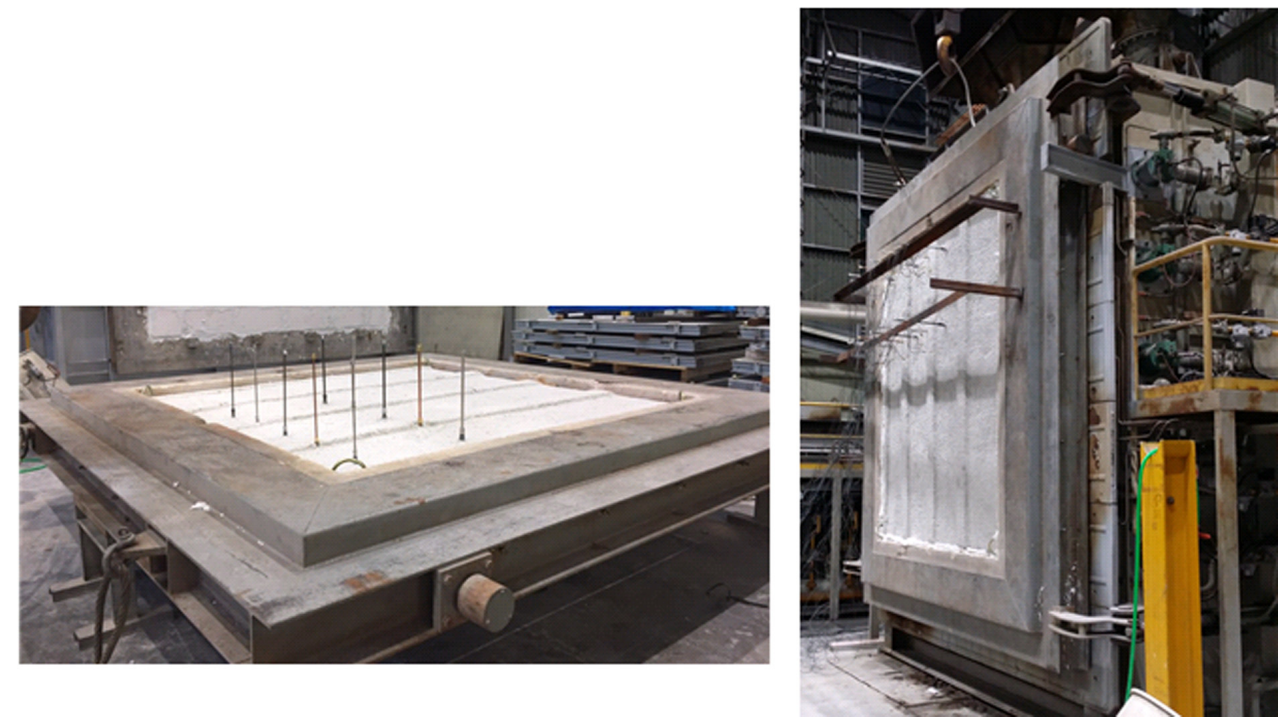

Fig. 6 Actual fire test specimen with spray type insulation(left) and installation on vertical furnace(right)
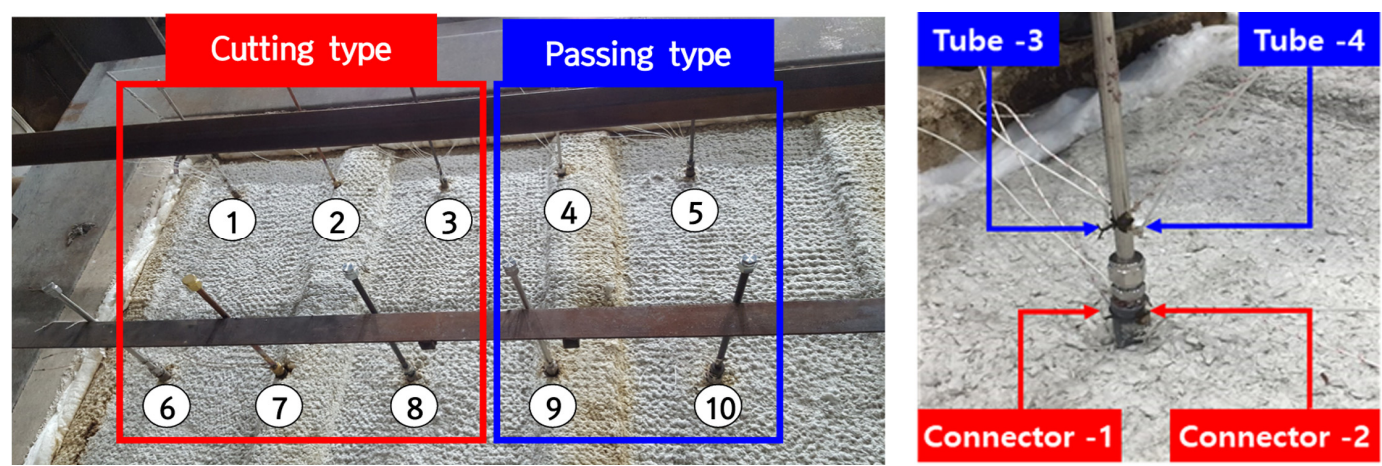

Fig. 7 Overall thermocouple locations(left) and detailed location(right)

$\mathrm{BPP}$ 의 온도 측정 위치는 $\mathrm{A} 60$ 급 $\mathrm{BPP}$ 의 열전달 수치해석 연구 (Park et al., 2018)와 동일하게 설정하였다. 온도 측정을 위한 온 도센서 부착 설정사항은 Fig. 7에 자세히 나타내었다.

Fig. 7에 나타낸 바와 같이 $\mathrm{SSC}$ 의 보강재 위치에 분무된 단열
재의 높이로 인해 튜브에만 온도센서를 부착할 수 있는 경우인 2 번, 4번, 7번, 9번 BPP는 2개의 온도센서를 튜브에 부착하였고, 이 외에 단열재 높이에 영향을 받지 않아 온도센서 부착에 제 한이 없는 경우인 1번, 3 번, 5 번, 6 번, 8 번, 10 번 $\mathrm{BPP}$ 는 소켓에 2 
개, 튜브에 2개로써 총 4개의 온도센서를 부착하였다. MSC.307 (88)에 규정된 시험절차에 따라 60분간 방화시험을 수행하면서 화염 비노출면에서 $\mathrm{BPP}$ 의 온도를 측정하였고, 앞서 저자들이 수행하였던(Park et al., 2018) 과도 열전달 수치해석 결과를 검

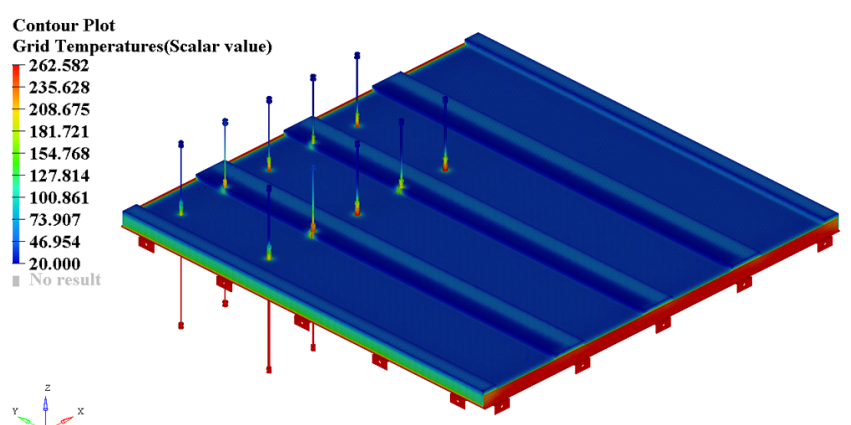

(a) Unexposed face
증하기 위해 BPP 상의 온도센서 부착 위치 별 온도결과를 비교 하여 Table 2에 나타내었다. 저자들이 수행하였던 기존 연구논 문(Park et al., 2018)에서 과도열전달해석에 따른 화염 비노출면 에서의 온도분포 결과는 Fig. 8에 도시하였다.

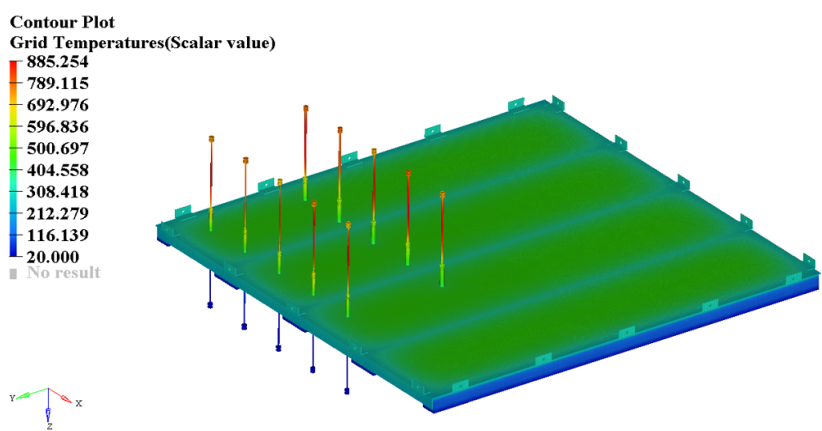

(b) Exposed face

Fig. 8 Temperature distribution contour results(Park et al., 2018)

Table 2 Comparison of temperature results for analysis and test (Park et al., 2018)

\begin{tabular}{|c|c|c|c|c|c|c|c|}
\hline \multirow{2}{*}{ ВРP \# } & \multirow{2}{*}{ Measuring point \# } & \multirow{2}{*}{ Material type } & \multicolumn{2}{|c|}{$\begin{array}{l}\text { Unexposed face } \\
\text { Temperature }\left[{ }^{\circ} \mathrm{C}\right]\end{array}$} & \multirow{2}{*}{ Error $[\%]$} & \multicolumn{2}{|c|}{ Remark } \\
\hline & & & Analysis & Test & & Analysis & Test \\
\hline \multirow{4}{*}{1} & 1-1 (socket) & SUS316L & 144.5 & 153.0 & 5.9 & $\mathrm{OK}$ & $\mathrm{OK}$ \\
\hline & $1-2$ (socket) & SUS316L & 144.4 & 132.5 & 8.3 & $\mathrm{OK}$ & $\mathrm{OK}$ \\
\hline & $1-3 \quad$ (tube) & SUS316L & 31.9 & 29.2 & 8.6 & OK & $\mathrm{OK}$ \\
\hline & $1-4$ (tube) & SUS316L & 32.0 & 27.9 & 12.8 & $\mathrm{OK}$ & $\mathrm{OK}$ \\
\hline \multirow{2}{*}{2} & $2-3$ (tube) & Brass & 169.7 & 196.7 & 15.9 & OK & Fail \\
\hline & 2-4 (tube) & Brass & 169.7 & 193.8 & 14.2 & $\mathrm{OK}$ & Fail \\
\hline \multirow{4}{*}{3} & 3-1 (socket) & $\mathrm{S} 45 \mathrm{C}$ & 210.2 & 220.5 & 4.9 & Fail & Fail \\
\hline & 3-2 (socket) & $\mathrm{S} 45 \mathrm{C}$ & 210.2 & 202.6 & 3.6 & Fail & Fail \\
\hline & 3-3 (tube) & $\mathrm{S} 45 \mathrm{C}$ & 84.5 & 82.7 & 2.1 & $\mathrm{OK}$ & $\mathrm{OK}$ \\
\hline & 3-4 (tube) & $\mathrm{S} 45 \mathrm{C}$ & 84.5 & 79.4 & 6.1 & $\mathrm{OK}$ & $\mathrm{OK}$ \\
\hline \multirow{2}{*}{4} & 4-3 (tube) & SUS316L & 102.3 & 115.3 & 12.7 & OK & $\mathrm{OK}$ \\
\hline & 4-4 (tube) & SUS316L & 102.3 & 109.9 & 7.4 & OK & $\mathrm{OK}$ \\
\hline \multirow{4}{*}{5} & 5-1 (socket) & $\mathrm{S} 45 \mathrm{C}$ & 213.9 & 221.3 & 3.5 & Fail & Fail \\
\hline & 5-2 (socket) & $\mathrm{S} 45 \mathrm{C}$ & 213.8 & 210.7 & 1.5 & Fail & Fail \\
\hline & 5-3 (tube) & $\mathrm{S} 45 \mathrm{C}$ & 81.2 & 77.5 & 4.6 & OK & $\mathrm{OK}$ \\
\hline & $5-4 \quad$ (tube) & $\mathrm{S} 45 \mathrm{C}$ & 81.2 & 76.8 & 5.5 & OK & $\mathrm{OK}$ \\
\hline \multirow{4}{*}{6} & 6-1 (socket) & SUS316L & 165.8 & 191.6 & 15.6 & OK & Fail \\
\hline & 6-2 (socket) & SUS316L & 165.8 & 159.0 & 4.1 & OK & $\mathrm{OK}$ \\
\hline & 6-3 (tube) & SUS316L & 35.2 & 34.4 & 2.4 & OK & $\mathrm{OK}$ \\
\hline & 6-4 (tube) & SUS316L & 35.1 & 31.2 & 11.0 & $\mathrm{OK}$ & $\mathrm{OK}$ \\
\hline \multirow{2}{*}{7} & $7-3$ (tube) & Brass & 186.4 & 218.4 & 17.2 & Fail & Fail \\
\hline & 7-4 (tube) & Brass & 186.4 & 213.4 & 14.5 & Fail & Fail \\
\hline \multirow{4}{*}{8} & 8-1 (socket) & $\mathrm{S} 45 \mathrm{C}$ & 230.9 & 233.5 & 1.1 & Fail & Fail \\
\hline & 8-2 (socket) & $\mathrm{S} 45 \mathrm{C}$ & 231.0 & 219.4 & 5.0 & Fail & Fail \\
\hline & 8-3 (tube) & $\mathrm{S} 45 \mathrm{C}$ & 93.0 & 86.7 & 6.8 & $\mathrm{OK}$ & $\mathrm{OK}$ \\
\hline & 8-4 (tube) & $\mathrm{S} 45 \mathrm{C}$ & 92.8 & 85.3 & 8.1 & $\mathrm{OK}$ & $\mathrm{OK}$ \\
\hline \multirow{2}{*}{9} & 9-3 (tube) & SUS316L & 108.7 & 97.0 & 10.7 & OK & $\mathrm{OK}$ \\
\hline & $9-4 \quad$ (tube) & SUS316L & 108.7 & 96.3 & 11.4 & $\mathrm{OK}$ & $\mathrm{OK}$ \\
\hline \multirow{4}{*}{10} & 10-1 (socket) & $\mathrm{S} 45 \mathrm{C}$ & 232.5 & 240.2 & 3.3 & Fail & Fail \\
\hline & 10-2 (socket) & $\mathrm{S} 45 \mathrm{C}$ & 232.5 & 223.5 & 3.9 & Fail & Fail \\
\hline & 10-3 (tube) & $\mathrm{S} 45 \mathrm{C}$ & 87.7 & 95.4 & 8.8 & $\mathrm{OK}$ & $\mathrm{OK}$ \\
\hline & 10-4 (tube) & $\mathrm{S} 45 \mathrm{C}$ & 87.6 & 92.1 & 5.1 & $\mathrm{OK}$ & $\mathrm{OK}$ \\
\hline
\end{tabular}


Table 2에 나타나 있는 바와 같이 방화시험 결과를 기준으로 과도열전달 수치해석의 온도결과 오차는 전체 측정위치에서 $17.2 \%$ 미만으로 나타났으며, Brass 재질인 경우에 상대적으로 오차가 높은 것으로 나타났다. Brass 재질인 경우 과도열전달 수치해석 결과에서 절단형으로 설계된 2번 $\mathrm{BPP}$ 는 규정 온도인 $180^{\circ} \mathrm{C}$ 이하를 만족하고 관통형으로 설계된 7번 $\mathrm{BPP}$ 는 규정 온도 를 만족하지 못할 것으로 예측 하였으나, 방화시험에서 모든 형 태의 $\mathrm{BPP}$ 에서 규정 온도를 만족하지 못하는 것으로 나타났다. Brass 재질의 $\mathrm{BPP}$ 에서 이와 같은 해석과 시험의 오차가 발생한 원인은 Fig. 9에 나타난 것처럼 방화시험 후 화염노출면에서 Brass 재질의 BPP가 융해되는 현상이 발생하였기 때문으로 사 료된다. $\mathrm{S} 45 \mathrm{C}$ 재질 $\mathrm{BPP}$ 의 경우 과도 열전달 수치해석 결과와 동일하게 모두 경우에서 규정 온도를 만족하지 못하는 것으로 나타났다. SUS316L 재질 $\mathrm{BPP}$ 의 경우 방화시험 결과에서 1 번, 4 번, 6번, 9번 BPP 중 6-1(Socket) 측정위치에서의 규정 온도인 $180^{\circ} \mathrm{C}$ 를 초과하는 것으로 나타났으며, 이러한 오차는 수치해석 상에서의 $\mathrm{BPP}$ 와 단열재의 연결 형태와 방화시험에서의 실제 연 결 형태의 차이에 기인 한 것으로 파악되어진다. 과도 열전달 수치해석에서 BPP와 단열재의 유한요소 모델은 절점(Node)을 공유하여 단열재와 $\mathrm{BPP}$ 간에 이격이 없는 이상적인 상태로 고 려되나, 실제 제작된 방화시험용 $\mathrm{SCC}$ 조립체의 경우 일부 $\mathrm{BPP}$ 와 단열재의 밀착이 잘 이루어지지 않아 오차가 발생한 것으로
판단된다. 그러나 전체적인 방화시험 온도 측정결과를 해석결 과와 비교해보면 오차율이 크지 않았고, 방화시험에 소요되는 비용과 시간을 고려하면 사전에 과도 열전달 수치해석에 기반 하여 설계 사양을 결정하는 것은 합리적인 접근 방법이라 할 수 있다. 방화시험 전·후의 재질에 따른 $\mathrm{BPP}$ 의 상태를 각각 관찰하기 위해 화염 노출면에서의 BPP 형상을 Fig. 9에 비교하 여 나타내었다.

Fig. 9에 나타난 바와 같이 Brass 재질인 2번, 7번 BPP에서 융 해가 일어남으로 인해 Brass 재질의 온도 특성(MatWeb, 2019) 상 $\mathrm{BPP}$ 의 소재로 적합하지 않은 것으로 나타났으며, $\mathrm{S} 45 \mathrm{C}$ 재질 인 3 번, 5 번, 8 번, 10 번 $\mathrm{BPP}$ 에서 방화시험 후에 변형이 발생한 것을 알 수 있다. 한편 과도 열전달 수치해석 연구에서 가장 합 리적인 $\mathrm{A} 60 \mathrm{BPP}$ 의 설계 사양으로 판단했던 $\mathrm{SUS} 316 \mathrm{~L}$ 재질인 1 번, 4번, 6번, 9번 $\mathrm{BPP}$ 는 방화시험 전후의 형상이 거의 동일하 게 유지되는 것으로 나타났다.

\section{3 단열재의 특성에 대한 방화시험 결과}

$\mathrm{A} 60$ 급 $\mathrm{BPP}$ 용 단열재의 종류에 따른 방화성능을 검토하기 위 해 부착식 단열재를 추가로 적용하여 방화시험 시편을 설계 및 제작하였다. 부착식 단열재는 선박 및 해양플랜트의 방화용 단 열재로 주로 적용되고 있는 W-212-II Hi Wool을 고려하였다. 부 착식 단열재 적용 $\mathrm{BPP}$ 의 방화시험에서는 앞서의 분무식 단열재
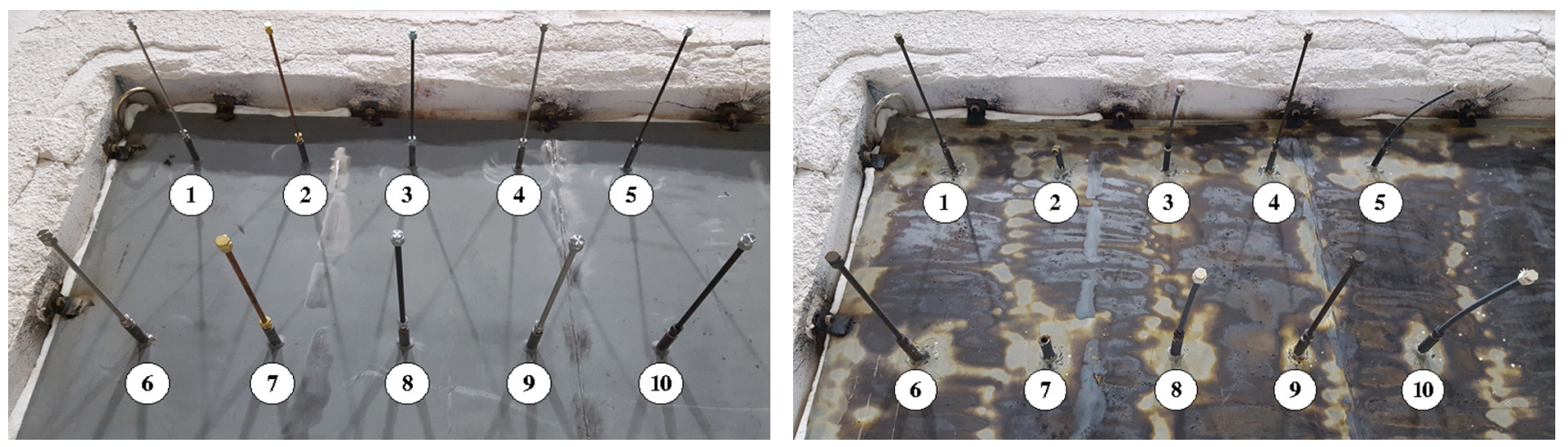

Fig. 9 Bulkhead penetration piece status before fire test(left) and after(right)
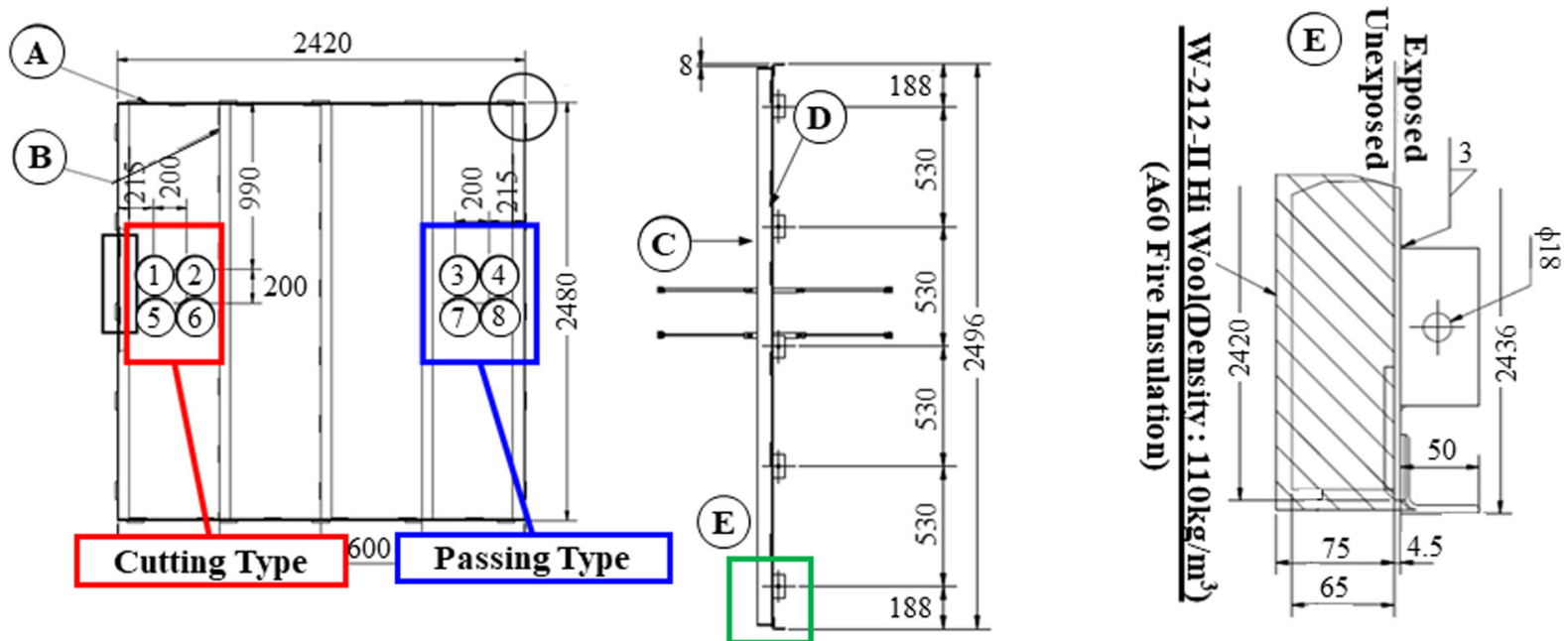

Fig. 10 Fire test specimen design for A60 class bulkhead penetration piece with mechanical fastener type insulation (Park et al., 2018) 
Table 3 Material type and main dimension of fire test specimen with mechanical fastener type insulation

\begin{tabular}{ccccc}
\hline \hline No. & Part name & Main dimension & Material type & Piece type \\
\hline 1 & Bulkhead penetration piece & $\phi 18$ Socket / $(\phi 8$ Tube $)$ & S45C / S45C & Cutting type \\
2 & Bulkhead penetration piece & $\phi 18$ Socket / $(\phi 8$ Tube $)$ & SUS316L / SUS316L & Cutting type \\
3 & Bulkhead penetration piece & $\phi 18$ Socket / $(\phi 8$ Tube $)$ & S45C / S45C & Passing type \\
4 & Bulkhead penetration piece & $\phi 18$ Socket $/(\phi 8$ Tube $)$ & SUS316L / SUS316L & Passing type \\
5 & Bulkhead penetration piece & $\phi 25$ Socket / $(\phi 12$ Tube $)$ & S45C / S45C & Cutting type \\
6 & Bulkhead penetration piece & $\phi 25$ Socket $/(\phi 12$ Tube $)$ & SUS316L / SUS316L & Cutting type \\
7 & Bulkhead penetration piece & $\phi 25$ Socket $/(\phi 12$ Tube $)$ & S45C / S45C & Passing type \\
8 & Bulkhead penetration piece & $\phi 25$ Socket $/(\phi 12$ Tube $)$ & SUS316L / SUS316L & Passing type \\
A & Bulkhead plate & $2420 \times 2480 \times 4.5 \mathrm{t}$ & Mild Steel & - \\
B & Bulkhead stiffener & $65 \times 65 \times 6 \mathrm{t}$ & Mild Steel & - \\
C & Sealing & $65 \times 6 \times 2420 \mathrm{~L}$ & Mild Steel & - \\
D & Mounting plate & $50 \times 50 \times 100 \mathrm{~L} \times 5 \mathrm{t}$ & Mild Steel & - \\
E & A60 fire insulation & $75 \mathrm{t}$ & W-212-II Hi Wool & - \\
\hline
\end{tabular}
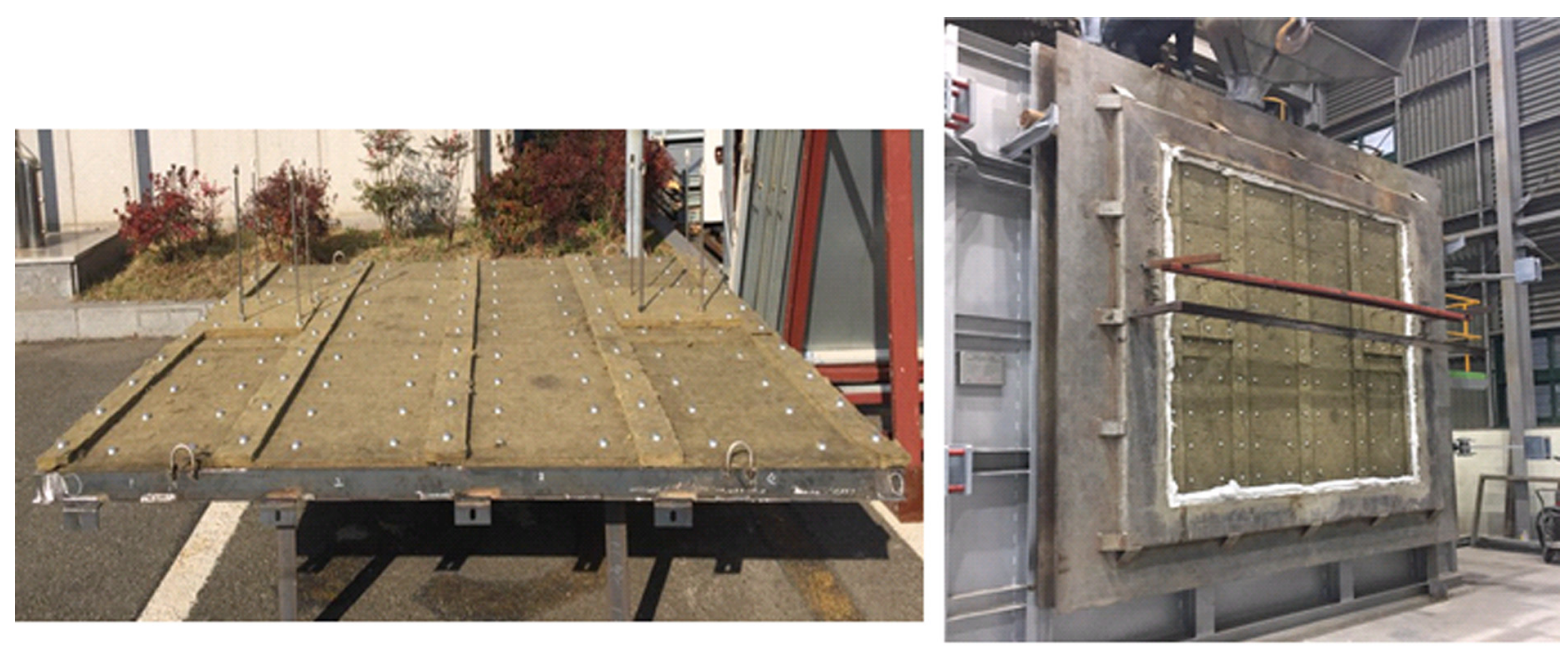

Fig. 11 Actual fire test specimen with mechanical fastener type insulation(left) and installation on vertical furnace(right)

적용 $\mathrm{BPP}$ 의 방화시험에서 $\mathrm{Brass}$ 재질 $\mathrm{BPP}$ 가 융해 되었기 때문 에 Brass 재질 $\mathrm{BPP}$ 를 제외하고 시편을 설계 및 제작하였다. 부 착식 단열재가 적용된 방화시험용 $\mathrm{SCC}$ 조립체의 설계사양은 Fig. 10과 Table 3에 나타내었다. Table 3에 나타나 있는 것처럼 $\mathrm{Brass}$ 재질 $\mathrm{BPP}$ 를 제외하고 $\mathrm{S} 45 \mathrm{C}$ 와 $\mathrm{SUS} 316 \mathrm{~L}$ 재질은 분무식 단 열재 적용 $\mathrm{BPP}$ 의 방화시험용 시편과 동일하게 설계 및 제작하 였다. 1 4번의 BPP는 $\phi 8$ 튜브와 $\phi 18$ 소켓의 조립체로 구성하였 고, 5 8번의 BPP는 $\phi 12$ 튜브와 $\phi 25$ 소켓의 조립체로 구성하였 으며, $\mathrm{BPP}$ 는 튜브와 소켓의 재질을 동일하게 설정하였다. 또한 1 2번, 5 6번 BPP는 절단형으로 고려하였으며 3 4번 및 7 8번 $\mathrm{BPP}$ 는 관통형으로 고려하였다.

Fig. 10과 Table 3에 나타나 있는 사양으로 실제 제작된 부착 식 단열재 적용 방화시험용 $\mathrm{SCC}$ 조립체의 형상과 $\mathrm{A} 60$ 방화시험 수행을 위해 수직화염로에 장착된 상태는 Fig. 11에 나타내었다.

부착식 단열재를 적용한 경우의 방화시험을 수행하기 전에 분무식 단열재와의 시공 상 특성을 비교하기 위해 Fig. 12와 같 이 $\mathrm{BPP}$ 조립위치에서 상세 형상을 관측하였다.
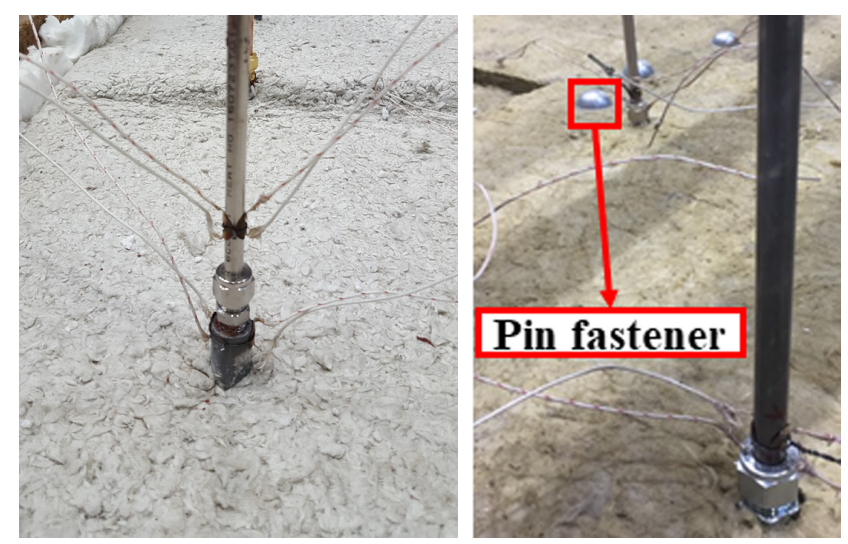

Fig. 12 Insulation assembly characteristics in spray type(left) and mechanical fastener type(right)

Fig. 12 좌측에 나타난 바와 같이 분무식 단열재는 울(Wool) 의 형태로 이루어진 단열재를 접착성분과 함께 분무하여 시공 하는 단열재로써 $\mathrm{BPP}$ 의 조립 형상에 영향을 받지 않아 울 형태 
Table 4 Comparison of temperature results for insulation type

\begin{tabular}{|c|c|c|c|c|c|c|c|c|c|c|}
\hline \multicolumn{6}{|c|}{ Spray type insulation } & \multicolumn{5}{|c|}{ Mechanical fastener type insulation } \\
\hline BPP \# & $\begin{array}{r}\text { Meas } \\
\text { poi }\end{array}$ & $\begin{array}{l}\text { suring } \\
\text { nt \# }\end{array}$ & Material & $\begin{array}{c}\text { Temperature } \\
{\left[{ }^{\circ} \mathrm{C}\right]}\end{array}$ & Remark & BPP \# & $\begin{array}{c}\text { Measuring } \\
\text { point \# }\end{array}$ & Material & $\begin{array}{c}\text { Temperature } \\
{\left[{ }^{\circ} \mathrm{C}\right]}\end{array}$ & Remark \\
\hline \multirow{2}{*}{1} & $1-3$ & (tube) & SUS316L & 29.2 & $\mathrm{OK}$ & \multirow{2}{*}{2} & $2-3$ (tube) & SUS316L & 199.7 & Fail \\
\hline & $1-4$ & (tube) & SUS316L & 27.9 & $\mathrm{OK}$ & & 2-4 (tube) & SUS316L & 181.7 & Fail \\
\hline \multirow{2}{*}{3} & $3-3$ & (tube) & $\mathrm{S} 45 \mathrm{C}$ & 82.7 & OK & \multirow{2}{*}{1} & $1-3$ (tube) & $\mathrm{S} 45 \mathrm{C}$ & 231.2 & Fail \\
\hline & & (tube) & $\mathrm{S} 45 \mathrm{C}$ & 79.4 & OK & & $1-4$ (tube) & $\mathrm{S} 45 \mathrm{C}$ & 217.4 & Fail \\
\hline \multirow{2}{*}{4} & $4-3$ & (tube) & SUS316L & 115.3 & $\mathrm{OK}$ & \multirow{2}{*}{4} & 4-3 (tube) & SUS316L & 225.4 & Fail \\
\hline & & (tube) & SUS316L & 109.9 & OK & & 4-4 (tube) & SUS316L & 209.7 & Fail \\
\hline \multirow{2}{*}{5} & $5-3$ & (tube) & S45C & 77.5 & OK & \multirow{2}{*}{3} & 3-3 (tube) & $\mathrm{S} 45 \mathrm{C}$ & 229.1 & Fail \\
\hline & & (tube) & $\mathrm{S} 45 \mathrm{C}$ & 76.8 & $\mathrm{OK}$ & & 3-4 (tube) & $\mathrm{S} 45 \mathrm{C}$ & 198.4 & Fail \\
\hline \multirow{2}{*}{6} & & (tube) & SUS316L & 34.4 & OK & \multirow{2}{*}{6} & 6-3 (tube) & SUS316L & 155.1 & OK \\
\hline & & (tube) & SUS316L & 31.2 & OK & & 6-4 (tube) & SUS316L & 155.1 & OK \\
\hline \multirow{2}{*}{8} & $8-3$ & (tube) & S45C & 86.7 & OK & \multirow{2}{*}{5} & 5-3 (tube) & $\mathrm{S} 45 \mathrm{C}$ & 245.0 & Fail \\
\hline & $8-4$ & (tube) & $\mathrm{S} 45 \mathrm{C}$ & 85.3 & $\mathrm{OK}$ & & 5-4 (tube) & $\mathrm{S} 45 \mathrm{C}$ & 244.4 & Fail \\
\hline \multirow{2}{*}{9} & $9-3$ & (tube) & SUS316L & 97.0 & OK & \multirow{2}{*}{8} & 8-3 (tube) & SUS316L & 216.9 & Fail \\
\hline & $9-4$ & (tube) & SUS316L & 96.3 & $\mathrm{OK}$ & & 8-4 (tube) & SUS316L & 203.5 & Fail \\
\hline \multirow{2}{*}{10} & $10-3$ & (tube) & $\mathrm{S} 45 \mathrm{C}$ & 95.4 & OK & \multirow{2}{*}{7} & 7-3 (tube) & $\mathrm{S} 45 \mathrm{C}$ & 245.4 & Fail \\
\hline & $10-4$ & (tube) & $\mathrm{S} 45 \mathrm{C}$ & 92.1 & $\mathrm{OK}$ & & 7-4 (tube) & $\mathrm{S} 45 \mathrm{C}$ & 230.0 & Fail \\
\hline
\end{tabular}

의 단열재에 비해 밀착되어 시공되어 있는 것을 확인할 수 있 다. 반면 Fig. 12 우측에 나타낸 부착식 단열재는 미네랄 울 (Mineral wool)을 판(Plate)형태로 제작하여 필요한 길이만큼 절 단하고 이를 핀으로 고정시키는 형태로써 단열재 고정용 핀을 격벽에 미리 용접해야 하는 준비과정이 필요하고, $\mathrm{BPP}$ 의 조립 부에서 완전한 밀착을 보장하기 어려운 것으로 나타났다. Table 4에는 MSC.307(88)에 규정된 시험절차에 따라 60분간 방화시험 을 수행하면서 부착식 단열재가 적용된 $\mathrm{A} 60$ 급 $\mathrm{BPP}$ 의 화염 비 노출면에서 온도를 측정하였고, 분무식 단열재의 결과와 비교 하였다.

Table 4에 나타난 것처럼 부착식 단열재가 적용된 A60급 BPP 의 규정 온도 만족 여부를 살펴보면 SUS316L 재질의 튜브사이 즈 $\phi 12$ 이며 절단형인 6 번 $\mathrm{BPP}$ 만 규정 온도를 만족하는 것으로 나타났다. 전체적으로 60 분 후 최종 측정 온도를 비교해 보면 부착식 단열재가 적용된 $\mathrm{BPP}$ 에서 최소 약 2 배에서 최대 약 7 배 의 온도 편차가 관측되었다. 이러한 원인은 Fig. 12에서 살펴본 바와 같이 부착식 단열재가 적용된 경우 $\mathrm{BPP}$ 의 조립부에서 단 열이 완전히 이루어지지 못하여 발생된 것으로 파악된다. 부착 식 단열재를 적용할 경우 $\mathrm{BPP}$ 의 조립부에서 완전한 밀착을 보 장할 수 있는 기술개발이 필요함을 알 수 있다. A60급 BPP와 같은 형상에 분무식 단열재를 적용할 경우 부착식 단열재에 비 해 $\mathrm{BPP}$ 의 형상에 따른 제약조건이 발생하지 않는 것으로 판단 된다. 분무식 단열재의 시공성이 평균적으로 우수하고, $\mathrm{BPP}$ 의 방화시험에서 최종 온도분포를 비교하였을 때 분무식 단열재를 시공한 $\mathrm{BPP}$ 의 전체적인 온도가 현저히 낮게 나타나는 것으로 보아 실질적으로 선박 및 해양플랜트의 A60급 BPP에는 분무식 단열재를 적용 하는 것이 타당하다고 판단된다.

\section{4. 결 론}

본 연구에서는 앞서 저자들이 수행하였던 $\mathrm{A} 60$ 급 구획에 적용 될 수 있는 $\mathrm{BPP}$ 의 설계와 과도 열전달 수치해석의 결과를 검증 하기 위해 $\mathrm{MSC}$ 에서 규정하고 있는 $\mathrm{A} 60$ 급 방화성능 검증에 대 한 화재시험절차와 동일하게 시편제작, 온도조건 및 가열시간 설정, 온도측정 및 분석방법을 준수하여 방화시험을 수행하였 다. 방화시험에 적용된 $\mathrm{BPP}$ 의 설계사양은 앞서의 수치해석 연 구에서 가장 경제성이 우수한 것으로 검토된 길이 $200 \mathrm{~mm}$ 를 기 준으로 설정 하였다. BPP 재질에 따른 수치해석 결과의 타당성 을 검증하기 위해 수치해석 연구와 동일하게 Brass, $\mathrm{S} 45 \mathrm{C}$, $\mathrm{SUS} 316 \mathrm{~L}$ 의 재질로 각각 $\mathrm{BPP}$ 를 제작하여 방화시험을 수행하였 다. 방화시험 결과로부터 Brass 재질인 경우 화염노출부에서 융 해가 발생하여 $\mathrm{BPP}$ 의 사양으로 적합하지 않음을 검증하였고, $\mathrm{S} 45 \mathrm{C}$ 재질인 경우 과도한 열변형이 발생하였으며 과도 열전달 수치해석에서 예측한 바와 같이 모두 규정 온도를 만족하지 못 한 것으로 나타났다. 과도 열전달 수치해석에서 가장 합리적인 $\mathrm{A} 60 \mathrm{BPP}$ 설계 사양으로 판단되었던 $\mathrm{SUS} 316 \mathrm{~L}$ 재질인 경우 외 관상 변형이 거의 발생하지 않았으며, BPP 6 번의 1 개의 측정부 를 제외하고 모두 규정온도를 만족하는 것으로 나타났다. 재질 별 $\mathrm{BPP}$ 에 대한 전체적인 방화시험 온도 측정결과를 과도 열전 달 해석결과와 비교해보면 오차율이 크지 않았고, 방화시험에 소요되는 비용과 시간을 고려하면 사전에 과도 열전달 수치해 석을 통해 $\mathrm{A} 60$ 급 $\mathrm{BPP}$ 의 설계 사양을 결정하는 것은 합리적인 접근 방법이라 할 수 있다. 단열재의 종류에 따른 방화시험 결 과로부터 부착식 단열재가 적용된 경우 SUS316L 재질의 튜브 사이즈 $\phi 12$ 이며 절단형인 6번 $\mathrm{BPP}$ 만 규정 온도를 만족하였고, 
이외의 설계사양은 모두 규정을 만족하지 못하는 것으로 나타 났다. A60급 BPP와 같은 형상에 분무식 단열재를 적용할 경우 부착식 단열재에 비해 $\mathrm{BPP}$ 의 형상에 따른 제약조건이 발생하지 않는 것으로 판단되었다. 분무식 단열재의 시공성이 평균적으 로 우수하고, $\mathrm{BPP}$ 의 방화시험에서 최종 온도분포를 비교하였을 때 분무식 단열재를 시공한 $\mathrm{BPP}$ 의 전체적인 온도가 현저히 낮 게 나타나는 것으로 보아 실질적으로 선박 및 해양플랜트의 $\mathrm{A} 60$ 급 $\mathrm{BPP}$ 에는 분무식 단열재를 적용 하는 것이 타당하다고 판단되었다. 저자들은 추후 부착식 단열재의 형상 제약사항을 개선할 수 있는 설계방안의 연구를 수행할 예정이다.

\section{후 기}

본 연구는 중소벤처기업부 위기지역 Scale-up R\&D 사업, 해 양수산부 해양장비개발 및 인프라구축사업인 '해양플랜트 플로 트오버 및 복수크레인 설치설계 핵심기술개발, 과제, 산업통상 자원부 '산업전문인력역량강화사업'의 친환경스마트선박 R\&D 전문인력양성사업의 연구결과 중 일부임을 밝힙니다.

\section{References}

Choi, J.M., Um, H.C., Jin, Y.H., 2014. Comparison on the Fire Performance of Additional Insulation Materials for Improving the Fire Retardancy in Engine-room of FRP Vessel. Journal of the Korean Society of Marine Engineering, 38(9), 1150-1155. https://doi.org/10.5916/jkosme.2014.38.9.1150

Choi, T.J., Kim, J.S., Choi, K.K., Lim, Y.S., Kim, Y.T., 2013.
An Experimental Study on the Fireproof of Fire Damper in Accordance with Insulation Conditions on the Coaming and Blade. Journal of the Korean Society of Marine Engineering, 37(4), 431-437. https://doi.org/10.5916/jkosme.2013.37.4.431

Grigonis, M., Maciulaitis. R., Lipinskas, D., 2011. Fire Resistance Tests of Various Fire Protective Coatings. Materials Science, 17(1), 93-98.

International Organization for Standardization (ISO), 1999. Fire Resistance Tests - Elements of Building Construction. ISO 834-1, Switzerland.

Jang, C.J., Hur, N.S., Kim, I.W., 2014. Performance Experiment of H-120 Class Fire Damper for Offshore. Journal of the Korean Society of Manufacturing Process Engineers, 13(2), 131-136. https://doi.org/10.14775/ksmpe.2014.13.2.131

MatWeb, 2019. Overview of materials for Brass. [Online] Available at : <http://www.matweb.com/> [Accessed 14 January. 2019].

MSC, 2010. Adoption of the International Code for Application of Fire Test Procedures. MSC.307(88), UK.

Park, W.C., Song, C.Y., Na, O.G., 2018. Heat Transfer Characteristics of Bulkhead Penetration Piece for A60 Class Compartment I: Transient Thermal Analysis for Piece Design. Journal of Ocean Engineering and Technology, 32(5), 310-323. https://doi.org/10.26748/KSOE.2018.6.32.5.310

Yu, J.S., Sung, H.G., Oh, J.H., 2000. An Experimental Study on Fire-Resistant Boom. Journal of the Korean Society of Marine Environmental Engineering, 3(2), 25-32. 